NBER WORKING PAPER SERIES

\title{
PERSONNEL ECONOMICS: THE ECONOMIST'S VIEW OF HUMAN RESOURCES
}

\author{
Edward P. Lazear \\ Kathryn L. Shaw \\ Working Paper 13653 \\ http://www.nber.org/papers/w13653 \\ NATIONAL BUREAU OF ECONOMIC RESEARCH \\ 1050 Massachusetts Avenue \\ Cambridge, MA 02138 \\ November 2007
}

Forthcoming, 2007, Journal of Economic Perspectives. Edward P. Lazear is on leave as Chairman of the President's Council of Economic Advisers, Washington, D.C. We thank Tim Taylor and Ann Norman, of the Journal of Economic Perspectives, for their detailed suggestions and editorial assistance. The views expressed herein are those of the author(s) and do not necessarily reflect the views of the National Bureau of Economic Research.

(C) 2007 by Edward P. Lazear and Kathryn L. Shaw. All rights reserved. Short sections of text, not to exceed two paragraphs, may be quoted without explicit permission provided that full credit, including (c) notice, is given to the source. 
Personnel Economics: The Economist's View of Human Resources

Edward P. Lazear and Kathryn L. Shaw

NBER Working Paper No. 13653

November 2007

JEL No. J01,J24,J3,J31,J32,J33

\begin{abstract}
Personnel economics drills deeply into the firm to study human resource management practices like compensation, hiring practices, training, and teamwork. Many questions are asked. Why should pay vary across workers within firms--and how "compressed" should pay be within firms? Should firms pay workers for their performance on the job or for their skills or hours of work? How are pay and promotions structured across jobs to induce optimal effort from employees? Why do firms use teams and how are teams used most effectively? How should all these human resource management practices, from incentive pay to teamwork, be combined within firms? Personnel economics offers new tools and new answers to these questions.

In this paper, we display the tools and principles of personnel economics through a series of models aimed at addressing the questions posed above. We focus on the building blocks that form the foundation of personnel economics: the assumptions that both the worker and the firm are rational maximizing agents; that labor markets and product markets must reach some price-quantity equilibrium; that markets are efficient or that market failures have introduced inefficiencies; and that the use of econometrics and experimental techniques has advanced our ability to identify underlying causal relationships.
\end{abstract}

\author{
Edward P. Lazear \\ Graduate School of Business \\ and Hoover Institution \\ Stanford University \\ Stanford, CA 94305-5015 \\ (on leave) \\ and NBER \\ lazear@gsb.stanford.edu \\ Kathryn L. Shaw \\ GSB, Littlefield 339 \\ Stanford University \\ Stanford, CA 94305-5015 \\ and NBER \\ kathryns@gsb.stanford.edu
}


Personnel economics drills deeply into the firm to study human resource management practices like compensation, hiring practices, training, and teamwork. Many questions are asked. Why should pay vary across workers within firms - and how "compressed” should pay be within firms? Should firms pay workers for their performance on the job or for their skills or hours of work? How are pay and promotions structured across jobs to induce optimal effort from employees? Why do firms use teams and how are teams used most effectively? How should all these human resource management practices, from incentive pay to teamwork, be combined within firms? Personnel economists offer new tools to analyze these questions - and new answers as well.

In the not-too-distant past, the typical textbook on human resources management would often eschew generalization, arguing that each situation is different. The economist's approach is the opposite. Rather than thinking of each human resources event as separate and institutionally driven, economists place a premium on identifying the underlying general principles, and on using specific institutional details to identify the causal sources of the general principles. Four primary building blocks from economics form the foundation of personnel economics: First, personnel economics assumes that both the worker and the firm are rational maximizing agents, seeking utility and profits. Of course, the economic approach allows for constraints or imperfections, such as imperfect information and transaction costs, and permits an individual's utility to be influenced by a variety of factors such as personal identity, competition, and peer pressure. Second, personnel economists assume that labor markets and product markets must reach some price-quantity equilibrium, which provides discipline for our models. Third, efficiency is a central concept of personnel economics. In the many circumstances in which inefficiencies arise, the economist pushes the analysis to another level by asking where equilibrating market forces might have failed, and asking what actions firms and/or workers might take to reduce the inefficiency. Fourth, personnel economists emphasize the use of econometrics and experimental design to identify underlying causal relationships. For example, some firms observe that if the firm moves to piece rate pay, productivity rises. However, it turns out that piece rate pay induces the most productive workers to join the firm, as well as changing the productivity of existing workers. 
During the last 25 years, as personnel economics has emerged as a field, human resources practices have systematically changed. For example, compensation now varies much more highly across individuals. In 1974, the $90^{\text {th }}$ percentile of wage earners received about 1.9 times the hourly wage of the $50^{\text {th }}$ percentile, but this multiple has risen steadily over the last three decades and has now reached about 2.3. Meanwhile the ratio of the hourly wage paid to the $50^{\text {th }}$ percentile of wage earners compared to the $10^{\text {th }}$ percentile rose somewhat from about 1.9 in 1974 to 2.1 over the next three decades, but since then has sagged back to a ratio of about 2.0. In other words, wage inequality has risen markedly mainly because the upper tail of high earners has grown (Autor, Katz, and Kearney, 2006, forthcoming). This rising variance of pay has occurred within occupations and across occupations. The variance of pay has also risen within firms and across firms.

The rising variance of pay across individuals surely reflects changing demand for skills, but also is likely to reflect changes in human resource practices. Compensation has shifted towards pay-for-performance. The proportion of employee's pay that comes from bonuses rather than from base salary has increased. Table 1A shows that the share of large firms that have more than 20 percent of their workforce working with some form of individual incentives, like a performance bonus, has grown from 38 percent to 67 percent. The percent of firms using any form of "gain-sharing" or group-based incentives has grown from 26 percent to 53 percent.

Teamwork has become prevalent in many firms. Firms reported pronounced increases in teamwork since the 1980s, as shown in Table 1B. From 1987 to 1996, the share of large firms that have more than 20 percent of their workers in problem-solving teams rose from 37 percent to 66 percent. The percent of large firms with workers in self-managed work teams rose from 27 percent to 78 percent. Team use seems to have reached a plateau in the later 1990s, but it's a high-level plateau.

Personnel economics is aimed at modeling firms' use of optimal management practices that have contributed to these trends. In what follows, we examine topics that have become fixtures of personnel economics and attempt to demonstrate how the notions of maximization, equilibrium, efficiency, and econometric modeling have enabled economists to further the understanding of human resources management. 


\section{Promotions and Raises}

In many large corporations with hierarchical management structures, wages show discrete jumps between levels of the hierarchy, rather than continuous increases. For example, Jack Welch left General Electric in 2001, when he earned \$4 million in base pay as chief executive officer. He was succeeded by Jeffrey Immelt, who earned $\$ 2.75$ million in base pay in his first year as chief executive office. But in the previous year, Immelt had been a vice president earning \$1 million (General Electric Corporation, 2001). Why did Immelt's value to the company more than double from one day to the next? The annual reports of public companies are rife with comparable examples in which a job promotion at the upper executive levels brings a very large salary increase.

In standard human capital theory, wages are determined by skills, and no conceivable story would allow Immelt's skills to increase dramatically a few minutes before he was promoted. Yet this flies in the face of common patterns of managerial compensation. It appears that jobs themselves - particularly high-level management jobs-play a large role in determining the wages of the jobholder. When Immelt took the top job at General Electric, reports stated that "the Welch protégé won a valuable prize” and Welch agreed that "He got a hellava raise, I’ll tell you that” (“GE's Talent Agency,” Time, December 3, 2000). Analogously standard notions of competition do not seem to work in this context either. Why didn't the other strong candidates for the chief executive officer job offer to work for wages much lower than those currently being paid to Immelt, bidding down his wage to close to his previous level?

Something else must be going on. Tournament theory, as it has come to be called, provides an integrated theory of compensation at different levels of the hierarchy (Lazear and Rosen, 1981; Green and Stokey, 1983; Nalebuff and Stiglitz, 1983). It addresses how pay raises are associated with promotions and argues that these compensation levels are not necessarily linked with a naive notion of productivity. However, productivity in a broader sense does influence compensation and is in part determined by it, through an incentive structure. At its heart, tournament theory makes the point that promotions are a relative gain. Individuals are promoted not on the basis of their absolute performance, but on the basis of their relative position in the organization. Furthermore, the compensation at one level does not necessarily serve to motivate individuals currently working at that level, but instead motivates all of those 
below that level who strive to be promoted. The theory reconciles directly the initial puzzle that individuals are promoted to jobs and then receive wages associated with those jobs that seem out of line with their previously recognized skill levels.

Tournament theory begins with the notion that prizes are fixed in advance. In other words, wages are associated, to a first approximation, with jobs rather than with the individual who holds the job. A vice president who is promoted to president receives the salary of a presidenteven when that salary is considerably different from the salary previously received. Winning that salary depends on relative performance. Individuals are promoted not because they are good, but because they are better than others within the relevant group. Promotion is a statement about relative position within the firm, not necessarily about absolute performance. The best worker receives the promotion even if many of the other workers are excellent.

The larger the pay spread between promotions, the larger the incentive to put forth effort. Consider a tennis match where winner and loser both receive the same prize. There is no doubt that individuals generally prefer to win, because pride and other factors may be involved. But winning becomes more important if the winner's prize is significantly larger than the loser's prize. In tennis, players may practice harder, forego other competitions, or just focus more on winning when the prize difference is greater. Similarly, in a corporate hierarchy, a large difference between the salary of the president and the vice president makes vice presidents more interested in becoming president, and they put forth considerable effort to get to that job. Similarly, at lower levels of the hierarchy, newly minted MBAs, lawyers, and assistant professors work extremely hard so that they can be promoted, or make partner, or obtain tenure. Accounting firms, law firms, and large corporations all motivate their managerial employees at least in part by the hope of promotion.

The tournament model also sets limits on the size of pay spreads. Very large pay spreads induce high effort, but they also create a work environment in the firm that is not very pleasant. If individuals are working at a very high level of intensity—say, 80-90 hours a week—it will be necessary to compensate those employees at a very high level. At some point, the additional cost to sustain that level of effort will not be justified by the output. In addition, individuals who are competing with one another can either seek to outperform others, or they can contribute to the failure of others. Such incentives can result in collusion (Dye, 1984) or in sabotage (Lazear, 
1989). Thus, pay structure must strike a balance between providing incentives for effort and reducing the adverse consequences associated with this kind of industrial politics.

Outsiders can change the nature of internal tournaments. If workers must compete not only with their coworkers, but also potentially with those employed in other firms, incentives are diluted. Chan (1996) argues that this is why firms tend to give preference to insiders over outsiders. Outsiders are hired only when they are substantially better than insiders. The evidence is that those hired from the outside move on a faster track than the typical insider at the same position.

Of course, chief executive officers currently receive a significant portion of their compensation in the form of bonuses or stock and stock options. When Jack Welch retired as chief executive office of General Electric in 2001, his annual bonus was \$12.5 million. During Immelt's first year as chief executive officer, his bonus was $\$ 3.5$ million. This pattern is consistent with tournament theory because for chief executive officers who are already at the top rung of the hierarchical ladder, relative compensation cannot serve as their motivation. Because the output of a chief executive officer is the profitability of the firm, stock and stock options are a reasonable metric of their output: in effect, chief executive officers switch from tournamentlike pay to piece rate pay (Rosen, 1986).

Tournament theory has significant empirical support. The structure of wages within firms and their patterns of promotion are generally consistent with tournament theory (DeVaro, 2006; Eriksson, 1999). The structure of prizes does seem to have a direct effect on the level of effort or resources devoted to an activity. For example, Knoeber and Thurman (1994) show that the size of the spread affects output in the broiler chicken industry. Ehrenberg and Bognanno (1990) were among the first to show that effort was responsive to prizes by looking at the scores that golfers obtained in contests. In experimental work, subjects behave almost exactly as tournament theory would suggest (Falk and Fehr, 2006). Drago and Garvey (1998) use a sample of Australian firms to show that when promotion incentives are strong, individuals put more effort into their jobs (as measured by absenteeism), but are also less likely to work cooperatively.

For explaining the large discrete jumps in compensation that accompany major promotions, tournament theory is pretty much the only game in town. It has stood the test of empirical evidence, it has not been displaced by other theories, and it is consistent with common sense and standard business vernacular. Indeed, the competition for the job of chief executive 
officer at General Electric largely came down to three individuals: Jeffrey Immelt, Bob Nardelli, and Jim McNerney. When Immelt got the job, Nardelli went to Home Depot and McNerney to 3M. When asked later about the competition for the General Electric top job, Bob Nardelli said “Look, you don't get to these jobs without being competitive. Any CEO will harbor that competitive spirit. It’s not against Jeff [Immelt] or Jim [McNerney]. You want to win. You don't want to win at their expense, you just want to win” (USA Today, 2007). This language certainly sounds like someone who recognizes his own participation in a competitive tournament.

\section{Choice of Compensation Structure and the Hiring and Retention of Employees}

In some firms, most workers are paid a salary. In other firms, bonuses or performance pay are a big portion of compensation. A survey done by Payscale.com looked at median salary and bonuses for a sample of occupations in a major metropolitan area. The median bonus for administrative assistants, social workers, and nurses is a small percentage of total compensation-less than 2 percent. The median bonus of a salesperson is $\$ 30,000$ for nonpharmaceutical sales and almost $\$ 40,000$ for pharmaceutical sales. The median salaries of these types of salespersons are $\$ 44,000$ and $\$ 58,500$, respectively, roughly on par with the median registered nurse's salary. For salespersons, bonuses make up over 40 percent of total compensation. Pay on the basis of output also extends to much more highly paid jobs, such as investment bankers, who are paid for the performance of the merger they just achieved, or hedge fund managers, who are paid for the performance of the fund they manage. For executive-level positions such as senior vice presidents and chief executive officers, the portion of compensation paid in bonuses is even larger, and in fact bonuses often far exceed base salary.

Why do some jobs pay workers an hourly wage or salary and other jobs pay based on the workers' performance? Clearly, part of the answer lies in our examples: it is easier, or less costly, to measure the output of salespeople than nurses. While the cost of measuring output is important in our model, we will tie it to other key features of employment that build on the concepts of equilibrating markets and rational decision makers. We will also suggest answers to 
some important broader questions: How should firms structure pay for optimal retention of workers? How should firms avoid losing "star” workers?

Assume that workers in an occupation, such as a portfolio manager at a hedge fund, have output, $q$, that varies across workers in the occupation in a typical bell-curve-shaped distribution shown in Figure 1. Each individual's output is initially unknown to the firm, because output is costly to measure. However, the firm can measure each individual's output at some cost. The firm has two options. First, the firm can forego measurement, in which case no measurement cost is incurred and no information about worker ability is ever revealed. A firm of this sort pays a straight salary, which must equal the average output. Second, the firm can measure the output of the employees and pay workers according to their individual output, which is "pay for performance.” In this case, the distribution of pay matches the distribution of output, minus the measurement costs.

The question is whether the firm should pay a straight salary-pay all workers on the basis of input and ignore individual variations in output-or pay on the basis of measured individual output. Thus, workers will be willing to come to a piece rate firm if and only if their expected pay in a setting of piece rates with measurement exceeds their pay in a setting of salary without measurement. The key is for a firm to choose the human resources practices-pay-forperformance versus salary_based on the firm's ability to attract the "right” workers for the firm. This model provides several important results.

A first implication of this model is that firms will pay for performance when it is cheaper to measure performance. When measurement costs are low, good workers will demand that their output be measured. For example, hedge fund trading is cheap to measure-success is readily quantifiable and relatively near term — so if one firm pays all traders the same mean wage, the best traders will leave to work for a firm that does pay for their performance (or will start their own firm). In Figure 1, the best workers, in area A, will leave the hedge fund firm if the firm pays an average wage rather than using pay for performance. In contrast, in commercial banking, it takes years for portfolios to mature, so firms pay average wages for input, such as hours at the loan desk. ${ }^{1}$ This model is about self-selection, or "fit." Those people who have the skills for

\footnotetext{
${ }^{1}$ There are other dimensions of output, such as client relations and business development. Sometimes, compensation schemes build in bonuses for superior performance along these dimensions. Furthermore, revenue is
} 
hedge fund trading, such as working under pressure to perform, will gravitate towards this occupation when it does pay for performance. In contrast, individuals who excel at working with loan customers will head towards commercial banking. In this case, the firm pays a salary, and then must screen using interviews, experience, and education, as signals of talent. Alternatively, if the costs of firing are low, firms will hire a range of workers in the full distribution of Figure 1, then fire for poor performance (Lazear, 1986). Ultimately, one advantage of pay based on measured output is that individuals who are not well suited to the required tasks are provided information that allows them to engage in an alternative activity.

The lower the cost of measuring output, the greater the likelihood that pay is a function of output. If we look at pay by occupation, we see that pay for output does rise with our general notion of the ease of measuring output. Empirical research confirms this: Brown (1990) and Drago and Heywood (1995) show that piece rates are less common when monitoring costs are higher, a finding in line with the theoretical prediction. (However, Brown (1992) shows that salaried workers whose salaries are tied to supervisor ratings, do not earn more than their unsupervised colleagues, in contrast to the theoretical prediction.) We would also expect that, if the cost of measuring output is decreasing over time-due to information technologies, for example - then more firms should pay for performance. Anecdotal evidence suggests that these patterns hold true, although more systematic analysis remains to be done (Andersson, Freedman, Haltiwanger, Lane, and Shaw, 2006).

A second implication of this model is that firms are more likely to pay for performance as the worker's alternative wage offers approach the value at the current firm. When a worker has alternative high-paying jobs, it is important for the firm to pay the worker for what they produce or the firm will lose the worker. One example is job-hopping in Silicon Valley (Fallick, Fleischman, and Rebitzer, forthcoming). In the earlier years, computer programming skills would often be firm-specific (as for Oracle or Microsoft). As Silicon Valley developed, and markets thickened, many firms could now make use of what were once firm-specific skills, and mobility rose. More mobility is consistent with fewer firm-specific skills. It also implies that wages should be more variable across workers in the new environment.

not profit, so incentives are sometimes made product-specific to prevent salespeople from selling high-price, lowmargin goods. 
This insight has implications for attracting and retaining workers. Workers with firmspecific human capital will find that current productivity is likely to be much greater than their alternative productivity in another job, and so they are less likely to be paid on the basis of output. Being paid for individual performance is also more likely to occur when a worker is young, before a great deal of specific human capital is acquired. Thus, the best time to sort workers is when they are young. As a corollary, senior people in the firm are less likely to be measured. Tenure reviews and decisions to promote to partner take place early in careers for this reason.

Third, as the lower tail in the distribution of worker quality like Figure 1 gets larger, performance pay is more likely to be optimal. A larger lower tail means that the value of weeding out low quality workers rises.

Thus far, we have emphasized how the choice between pay for performance and salary leads to selection and sorting among workers. Conversely, we have ignored the possibility that paying for performance can induce people to work harder. Naturally, economists have also emphasized that some people are likely to work harder when there are tangible rewards. Workers with a high disutility of effort relative to their output will avoid firms that pay for performance. Workers are heterogeneous - those who value intrinsic internal motivation more than extrinsic rewards will gravitate towards jobs with salary or wage-based pay: not everyone would enjoy the risk and rewards and work environment of being a hedge fund manager. This feature could be added to the model above, and it would introduce additional issues that we will not expand upon here. Nonetheless, we can look in the data to see if pay-for-performance raises output.

The likelihood that pay-for-performance will encourage more effort raises some questions about identifying causal relationships carefully. For example, hedge fund managers earn more than do commercial bankers. Since hedge fund managers have a larger portion of income paid in incentive pay, an unwary human resources person might conclude that paying for output makes workers more productive. However, putting in place an output-based pay plan for commercial bankers might well provide only very limited results.

Why might this be the case? First, it takes time for those who are best at selling loans to switch to those jobs. Thus, productivity gains from moving to a commission-based system for loan officers may be smaller in the short run than in the long run. Second, measuring the performance of commercial bankers may prove tricky. For example, a bank that sets pay based 
on the number of loans may find that the rate of loan defaults increases. If a number of those defaults happen only several years into the future, the commercial bank may find itself better off just paying salary. Third, loan officers may never be as productive as investment bankers, because successful investment bankers produce a higher dollar value-added (or productivity) per unit of effort than do commercial bankers. In keeping with the higher productivity of investment banking, the firm must hire more highly talented people as investment bankers, and pay them more. If a human resources manager does not consider such selection effects, the gains from implementing an incentive pay program may be much lower than expected.

What do the data tell us? Performance pay is used to induce selection by workers into the right jobs. For example, Lazear (2000) provides an example of a firm that installs windshields: individual workers drive their trucks to customers with damaged windshields and install new windshields. When the firm switches from hourly pay to piece rate pay, the average daily productivity goes from two windshields to three. Some of the increase would be due to the rewards for performance. About half probably comes from selecting workers who can respond to those incentives (by exerting more effort) and about half from selecting workers who can respond to those incentives with high effort or talent.

Numerous other studies find performance gains and selection effects from performance pay. Other evidence exists on how workers respond when presented with varying compensation schemes. Asch (1990) presents evidence that Navy recruiters vary their recruitment effort in response to incentives. Using data on jockeys, Fernie and Metcalf (1999) show that incentive contracts generate superior performance to other, noncontingent payment systems. Using an experiment in a tree-planting firm, Shearer (2004) shows a productivity gain of around 20 percent when worker compensation was switched from a fixed wage to a piece rate system. Freeman and Kleiner (2005) do find that productivity falls when switching from piece rates to salary pay, but profitability rises because performance pay undermines other goals, such as lowering inventories. Similarly, Lo, Ghosh, and Lafontaine (2006) show that salesmen of industrial products are offered contracts with piece rate pay in part to increase personal performance and in part to induce the selection of salespeople who respond well to that type of contract. In a survey of firms across industries, Parent (1999) documents the existence of an incentive effect whereby men who are paid a piece rate are induced to work harder/more efficiently. 
Thus, personnel economics provides implications for the structure of pay across occupations and experience levels. The choice between pay-for-performance and salary is determined by concerns of economic efficiency in different employment settings, including the level of measurement costs and the value of screening out workers to specific employers.

\section{Pay Compression}

Another element of the choice of compensation is whether, within a firm, the firm's pattern of pay for individuals should have less variance than does individual performance. No systematic data exists on individual output, so no one knows whether pay is generally more compressed than output within firms. ${ }^{2}$ Nevertheless, managers and human resource professionals within firms do have a sense that pay is more compressed than output, and often ask the question, how compressed should pay be?

The often-stated objective of a more compressed pay structure is to make pay more equitable. People do seem to value equity or fairness in pay (Baron and Kreps, 1999). However, fairness is a slippery concept. Is it fair to pay all workers the same amount, or does fairness require that workers are paid in proportion to their output? What if output results from inherent differences in ability rather than choice about effort? If endowed ability is viewed as luck, should firms ignore these differences? If some firms did ignore differences in innate ability, what would happen in a competitive market where other firms that do pay on the basis of ability attract the most able workers and thereby lower costs relative to the compressed wage firms?

There are a number of reasons to believe that some degree of pay compression is an efficient market outcome. For example, perhaps a greater degree of equity or fairness produces higher productivity, perhaps through greater teamwork. This trade-off will vary across firms. For example, in firms with more team-based work, pay should be more compressed for

\footnotetext{
${ }^{2}$ The evidence on this is sketchy because pay and productivity are rarely measured in the same data set. The theory and popular literature on this are somewhat schizophrenic. In one paper, Frank (1985) argues that pay is compressed relative to productivity. Years later, Frank (1996) argues that pay is spread out too much because of the winnertake-all nature of pay in some occupations. In one dataset that has productivity and wage data, the variance in productivity is smaller than the variance in pay (Lazear, 1999b).
} 
numerous reasons: equity is more relevant in close comparisons, and individual output that would attract an outside wage offer is more difficult to disentangle from group results.

In the tournaments model above, workers may distinguish themselves not only by making themselves look good, but also by making their rivals look bad. When pay or other forms of rewards are based on relative performance, cooperation is discouraged as workers try to outshine their competition. To reduce the incentives to undermine coworkers, pay compression becomes part of optimal contracts. In general, pay compression reduces the incentives to engage in sabotage or other noncooperative behavior that is induced by the prisoner's-dilemma-style payoff structure (Lazear, 1989).

A related idea involves pay compression that results because workers try to influence their superiors (Milgrom, 1988; Prendergast, 1993). As the gains from appearing better than another in the firm increase, the incentives to lobby one's boss become greater. Pay compression serves to mitigate these effects.

Finally, pay may be compressed because it is efficient to have the firm insure workers against uncertain outcomes, like bad luck on the job or bad luck when sales fall due to market conditions. One difficulty with this kind of insurance is that it is subject to severe moral hazard problems. If workers know that they will be insured against low productivity outcomes, incentives to put forth effort are reduced.

It is difficult to test whether firms are compressing pay relative to output. If some firms compress pay, high-ability workers should leave those firms. Eventually, firms with compressed pay will be comprised entirely of "average” or below-average workers. In Lazear and Shaw (forthcoming), we don't find that that mobility rates are higher for high-wage people in firms with more compressed pay. But again, the data we have does not measure ability, so firms with compressed pay may already lack high-ability workers.

\section{Hedonic Wage Analysis and Nonmonetary Job Attributes}

Money isn’t everything. Employees care about more than pay. When asked, employees state that they care about flexible hours of work, comfortable working conditions, colleagues whom they enjoy, projects on which they enjoy working, and bosses who provide recognition 
and mentoring. Employees also care about the nonwage benefits, such as health insurance and pensions. However, preferences for these benefits vary across workers: older workers are more likely to care about pension benefits or high-quality health insurance than younger ones. The question is, should the firm offer more pensions, or more health insurance, or flexible hours? How do benefits affect the amount of base pay offered? The hedonic model of compensation provides a structure for firms to use in answering these questions.

Benefits are often costly. This fact is obvious in the case of pensions and health insurance, but even nonmonetary benefits, such as flexible work hours, can increase coordination costs for the firm. These benefits can also have productivity-enhancing effects: for example, pensions may cause productivity to rise as workers invest in more human capital and have a longer time horizon at the firm (Lazear, 1979), or flexibility may increase productivity as workers choose when best to work. However, the hedonic model tends to focus on the cost side of benefits, or at least to assume that productivity enhancements from benefits do not totally outweigh the costs. In this setting, a trade-off arises - if the firm offers more benefits, it must offer less pay. How should a firm strike the right balance between wages and benefits?

The key insight of the hedonic model is that a firm should offer the package of pay and benefits that will attract the workers it desires. The interaction between workers' preferences, the firm's cost structure, and the firm's desire to attract employees will determine how many benefits to offer.

The first and perhaps most obvious prediction of the hedonic model is that there is a negative trade-off between wages and "positive” job attributes, attributes like status or flexibility in hours of work.

A second key prediction of the hedonic model is that each firm offers the benefits that will attract the types of workers that the firm values the most. Consider an example from the software industry. SAS is a firm that produces statistical software licensed to big corporations, and their product's value comes from its very high re-licensing rate from its existing customers. Therefore, SAS wants software programmers who serve customers well by designing product upgrades that suit customer needs. To attract such programmers, SAS offers pension benefits and other family-friendly benefits. In contrast, the typical firm in Silicon Valley is less likely to provide pension benefits. These other software firms value software programmers who are younger and have the latest programming skills in new technologies. In turn, these young 
workers prefer high pay (and risky stock options) and state-of-the art programming projects over pensions.

A market equilibrium sorts workers to their optimal match or "fit" with firms. The firms that value loyalty among workers, like SAS, will offer pension benefits, and the workers who want stable long-term jobs will choose these firms and will give up some base salary to get the pension. The firms that value the skills of a young mobile workforce will not offer pensions, and the young workers will choose the high pay and stock options of these firms. The model tells us both how much the firm should offer in benefits and why they should offer particular benefits to attract certain types of workers.

Does the data support these two predictions of the model? At first glance, the data does not support the prediction that wages and benefits are negatively correlated. In fact, if we look at typical job attributes, such as pensions, health insurance, or safe working conditions, there is a positive correlation between these benefits and pay. As shown in Table 2, the percentage of individuals covered by employment-based health insurance rises with family income. However, simple correlations are not a fair test of the hedonic model. Simple correlations always produce an upward bias (or positive trade-off) because in the cross-sectional sample underlying these correlations a person's ability is not observed. People of higher ability will get both higher base pay and higher benefits than people of lower ability. A college-educated worker typically has both higher pay and benefits than a high-school educated worker, so as base pay rises, benefits rise. Since worker ability differences cannot be measured solely by education, cross-sectional regressions always suffer from an omitted ability bias that produces the positive pay-benefit correlation.

As a thought exercise, consider the sort of data needed to test for a negative trade-off between benefits and pay. Collect data on one person's job offers after they have gone to a broad range of firms that offer different pay packages, and see if a negative trade-off exists in their job offers. The closest we can come to this thought experiment is to follow individuals over time as they change jobs and see if there is a negative trade-off in pay packages. Studies of this type do find a small negative trade-off (Brown, 1980). However, this approach does not fully solve the selection problem: after all, individuals do not choose their new jobs randomly. The average software programmer in Silicon Valley who knows his pay-benefits preferences will not 
move to SAS; thus, we never estimate the true trade-off. Of course, that is the point of the model: benefits are used to cause workers to select the firm that values them the most.

This point leads to the test of our second prediction: do firms use benefits to encourage workers to sort to the firm that values them the most? The evidence shows workers sorting to firms based on benefits. Oyer (forthcoming) shows that workers match to the firms that offer the benefits each worker values. Stern (2004) looks at the pay of scientists and finds support for both predictions of the model. High-quality scientists often take cuts in pay in order to work on good projects, and firms offer them the projects and pay packages they desire.

After the basic theory of the hedonic model was developed by Rosen (1974; see also Thaler and Rosen, 1976), empirical methods essential for addressing selection issues evolved, allowing for new tests of the model. Methods for thinking experimentally using nonexperimental data improved our understanding of the hedonic model itself as well as the tests of it (Epple, 1987).

Viewing seeming nonmonetary attributes of the job as having trade-offs that can be monetized is a major breakthrough, because it means that any model in personnel economics can be applied to nonmonetary rewards just as well as to monetary incentives. For example, the tournaments model above, which discusses motivation in terms of prizes that take the form of higher salaries, can also be interpreted to refer to prizes that take the form of status or prestige, not money.

Hedonic analysis as done by economists is very different from approaches taken by other human resources scholars. The hedonic notion that everything can be monetized is anathema to the approach taken by industrial psychologists. Instead, those fields tend not to think in terms of trade-offs, but in terms of status or identity associated with positions (March, 1999). In these status or identity models, an individual may demand a particular feature of a job because it is consistent with his identity. Economists certainly introduce concepts of identity as well, but identity is added to an equilibrium model of rational decision making (see the next subsection on teams below).

Personnel economists explicitly think in terms of substitution and trade-offs, and firms have begun to do so as well. For example, for many years, most firms have had a benefits department that is distinct from the compensation department. Firms had thought in terms of providing some market level of each job attribute, rather than thinking in terms of a total package 
of utility for pay and for benefits. As firms have moved towards an emphasis on human resources as a strategic decision, these trade-offs are increasingly recognized. Simple evidence of this change is that workers are now given choices: flex benefits plans allow them to purchase different amounts of health care versus pay. The hedonic model also tells us that employees will not be offered the full range of choices. If the firm feels it has the right range of pension-pay packages to attract the workers it desires, it will not give workers additional choices.

In the personnel economics model, the provision of benefits and nonmonetary job attributes has little to do with identity or other external factors; instead, it is motivated by rational behavior and efficiency as firms seek out the kinds of workers they desire.

\section{Team Production}

Teamwork has increasingly become a way of life in many firms. From 1987 to 1996, for example, the share of large firms that have more than 20 percent of their workers in problemsolving teams rose from 37 percent to 66 percent, as shown earlier in Table 1 . The percent of large firms with workers in self-managed work teams rose from 27 percent to 78 percent. Team use seems to have hit a plateau in the 1990s; but it's a high plateau.

Why do so many workplaces now use teams? Teams can be time consuming to organize and coordinate, and the apparent slow progress of teams is nearly proverbial. Moreover, managers and team members always worry about the free-rider problem-that indolent individuals will free-ride on the effort of a few team members. So why do firms use teams? How should teams be managed? And what types of firms are likely to gain the most from teams?

One reason firms use teams is that team production can be more productive than individuals working alone. For example, suppose that the goal is to develop a new product. How should workers be organized to achieve this objective? In Figure 2, two different situations are depicted. Suppose that two skills, design and operations, are needed to produce a product. A point in the space reflects the amount of knowledge that an individual has in each of the two required skills.

In Figure 2A (the left-hand panel), individual 2 is strong on operation skills, but relatively weak on design skills. Individual 3 is strong on design, but weak on operations. If person 2 needs to think about design, person 3 is a good person to ask. If person 3 needs to think about 
operations, then person 2 is a good person to ask. If skills are distributed as in the left-hand panel, then team communication seems best because each person has an absolute advantage in one of the two skills. With teams, it is as if each member has access the good operations skills of person 2 and the good design skills of person 3, rather than only their own individual endowment of these skills. Note also that individual 1 has no area of greatest expertise, but may be sufficiently cheap to make hiring this person worthwhile.

Suppose instead that the situation is that shown in Figure 2B. Now, person 4 has an absolute advantage in both design and operations. If person 2 has a question about design, person 4 is a better resource than person 3. If person 3 has a question about operations, person 4 is a better resource than person 2. This setting is better-suited to a hierarchical organization, where person 4 is the supervisor to whom all go to consult.

When does the firm choose the Team versus Hierarchy? If individuals like type 4, who possess an absolute advantage in both skills, are more expensive because they are rare, firms will choose teams. Which firm types are likely to be willing to pay for the one-dimensional experts shown in the left-hand panel? Maybe new technologies would be more likely be associated with firms consisting of teams of experts, because in new technologies, rapid evolution of information makes it difficult for any one person to have an absolute advantage in everything. As technologies mature, very talented individuals may, over time, acquire knowledge in a multitude of skills, making a hierarchical structure more natural. It is also true that new technologies are associated with firms that introduce teamwork (Bartel, Ichniowski, and Shaw, forthcoming; Bloom and Van Reenen, 2007).

The model of teamwork introduces the importance of complementarity between the skills of different workers. When the design expert works with the operations expert, they produce a new product design that is better than the two individuals could have produced working independently. In other words, workers' inputs interact multiplicatively, so that each worker's marginal product is enhanced by combining effort with another worker who has different skills.

The figure emphasizes several features of team interaction that may be central to creating value in teamwork: Lazear (1999a) provides more detail. The first feature, which is especially clear in Figure2A, is “disjointness:” that is, the gains from team interaction are greater when individuals have different skills or different information. The second feature is relevance: that is, the skills of team members should not only be nonoverlapping, but also relevant. Third, 
teamwork requires communication, which can involve both common jargon and personal knowledge of each other. Communication costs are likely reduced over time as individuals learn to speak each others' languages.

Fourth, firms that need to solve complex problems quickly should use teams; firms that need to check decisions should be more hierarchical. Consider an example. Coke has invested heavily in its brand value and the shape of its traditional bottle. Any design alteration by a product design team should be checked very carefully, by many bosses up the hierarchy, before any new design could be launched. The example illustrates that team-based decision making is too costly when the bad decisions of team members can have very negative consequences for the firm. A generalist, such as person 4, will typically cost more than individual experts. Generalists, who can check the designs of experts, should be hired as well when the value to the firm is high. In contrast, a new firm, with no brand value, can risk letting the team of experts decide, because the risk of making a poor decision is less costly to the firm.

A variety of empirical evidence shows that teamwork can be more productive, for reasons based in the sources of productivity described above. The model of worker complementarity within teams is supported in Hamilton, Nickerson, and Owan (2003), which found that adoption of teams in a garment factory increased productivity on average by 14 percent and that more heterogeneous teams were more productive than teams of the same ability. Communication is also very important in teams. In a study of 700 workers in steel mills, workers in the mills with a team-based environment reported much higher levels of communication with all peers and supervisors than in the hierarchical mills (Ichniowski and Shaw, 2003). Given the increased communication required for teamwork, teams are more productive when communication costs are low. The firms that use teams the most are those that have complex problems to solve. For example, in a study of steel production, Boning, Ichniowski, and Shaw (forthcoming) show that team systems produce the greatest gains and are more likely to be adopted in steel mills that have complicated problems to solve because their products are complex.

The economic approach to team configuration is motivated primarily by an emphasis on complementarity of skills. Although other disciplines have loosely defined notions of complementary skills, the rigorous definitions of absolute and comparative advantage in economics provide specific implications. For example, it is not sufficient that one member has absolute advantage in a certain skill. It is necessary to understand the equilibrium wage 
differentials across individuals of different types to know whether one form of organization like hierarchy dominates another form like team production.

The U.S. economy has seen pronounced changes in the pricing of skills coinciding with the rise of teamwork. Since 1987, as discussed earlier, wage inequality has risen markedly, specifically the gap between the pay of workers at the $90^{\text {th }}$ percentile of the wage distribution and the median worker has grown yearly (Autor, Katz, and Kearney, 2006). In short, the wages of highly skilled "star" workers have grown relative to the typical employee (Anderson, Freedman, Halhwanger, Lane, and Shaw, 2006). Are these stars experts, like persons 2 and 3 in Figure 2, or generalists, like person 4? Perhaps both. Experts are highly valued: the inequality of wages has risen within very narrowly defined occupations. General skills are also valued: the underlying skill that is rising in demand (and pay) is "cognitive nonroutine problem solving skills" across all occupations (Autor, Levy, and Murnane, 2003). We do not have national data that combines information on firms' use of teams and the skills and wages of their employees. The data does suggest that firms are increasingly comprised of problem-solving experts, and firms are increasingly team-based.

\section{The Complementarity of Human Resource Management Practices and Organizational Transformation}

Firms are changing their human resources practices toward more incentive pay and more teamwork. Yet some managers report that their experiments with new practices have failed (for examples in the steel industry, see Ichniowski, Shaw, and Prennushi, 1997). Are there general principles that managers can follow that are more likely to produce successful results when they implement these practices?

When a new practice is introduced, it often requires supporting practices to be successful. For example, teams are more productive when workers are better trained, or are given team-based incentive pay, or are selected carefully for skills that are complementary. If the firm does not introduce all practices, the teams may well fail to produce higher output. Human resources practices can be complements, in the sense that doing more of one of them increases the returns to doing more of the others. Economists and noneconomists both 
emphasize the value of complementary practices (for example, Baron and Kreps, 1999; Pfeffer, 1994). Thus, when firms consider alternative human resource management practices, such as teamwork or incentive pay, they would be wise to consider the value of the collective set of practices rather than the value of individual practices.

Empirical evidence supports the claim that greater value can be obtained from introducing a set of complementary practices than from introducing individual human resources practices. Ichniowski, Shaw, and Prennushi (1997) gather data from four systems of human resource practices that are used in 35 steel mills. The mills that introduce a complete system of innovative practices_-such as group-based incentive pay, teamwork, careful hiring, high communications with workers, implicit job security, extensive training, and job flexibility-are substantially more productive than the mills that introduce a very limited set of teams.

Many other examples of the importance of complementary practices prevail (Roberts, 2004). Southwest Airlines uses a set of labor practices that focus on teamwork, training, and careful hiring that seem to result in a set of satisfied customers and fast turnaround time for planes. When traditional airlines attempt to compete with Southwest and fail, it is most likely because large airlines cannot introduce the entire set of practices that would mimic Southwest (O’Reilly, 1995).

Because human resources practices form complementary sets, in optimizing production, the choices firms have before them look like a mountain range-there are local peaks in output with valleys between them. In a traditional production function, firms increase labor to move up the peak towards the highest output, then hit diminishing returns to labor and slide down the side of the mountain. Instead of choosing amounts of labor, firms are choosing sets of complementary labor practices (Roberts, 2004). One peak in output arises when the firm chooses the complementary set of traditional labor practices: close monitoring of workers, little problem-solving, and workers doing their jobs alone. If the firm then introduces teams, output may fall, as this takes time away from production but does not raise output. The firm enters a valley, and does not get to another, perhaps higher, peak until it combines the entire set of practices that support teams. In the real world with adjustment costs, firms can't always make leaps from peak to peak, and may get trapped in a valley in the short run. Therefore, when firms change their human resource practices, they must know their ultimate goal and take the risk of a 
short-term fall in output. Moreover, individual managers cannot be given the power to make marginal changes in human resources practices.

Returning to the evidence from the steel industry, Ichniowski and Shaw (1995) show that steel mills rarely make big leaps to highly innovative practices, despite the evidence that the sets of innovative practices are ultimately successful. More broadly, Baron and Hannan (2002) follow about 200 start-up companies as they choose their human resources practices and change their practices over time. The evidence showing that firms form sets of complementary practices is strong and furthermore confirms that firms have difficulty leaping between these sets (Roberts, 2004).

\section{Conclusion}

For most of the last century, personnel, later called human resources management, was the territory of industrial psychologists and those who studied organizational behavior. But in the 1970s, economists began to bring the formalism and rigor of economic thinking to human resources. The model for personnel economics, the field that grew out of that endeavor, was modern finance. Finance was historically an institutional field without much theoretical or even empirical underpinning until the modern developments of scholars like Merton Miller, Harry Markowitz, William Sharpe, Eugene Fama, Fischer Black, Myron Scholes, Robert Merton, and many others who followed in their footsteps. These scholars transformed the field of finance into a branch of economics in large part by recognizing that a few basic principles, such as arbitrage, governed financial markets. Personnel economics has followed a similar path and is beginning to gain the prominence that modern finance has enjoyed.

What does personnel economics add to traditional methods of studying human resources management? Most labor economists who taught in business schools have traditionally encountered a disinterested audience. Traditional topics of labor supply and demand, unemployment, and investment in education, which are of primary concern to labor economists, are almost irrelevant to their business students. The issues studied by human resources specialists were of interest to economists, but the approach taken by the noneconomists lacked the formal framework to which economists have grown accustomed. The entry of economists into the field of human resources management was assisted by breakthroughs in agency and contract theory, 
which enabled economists to tackle problems that had evaded them in the past. Entry was further assisted by advancements in econometrics, including ways of addressing sample selection bias, omitted variable bias, and endogeneity, as well as by the use of panel data, which allowed economists to formulate and test models in a way that closely approximated experiments in the use of alternative human resource management practices.

In providing guidance to firms in the choice of their human resource management practices, several themes have emerged. Many of the models emphasize the importance of "fit." Firms and workers achieve fit when a worker's skill set, broadly understood, is matched to the firm that values it the most. Workers, or potential employees, have very heterogeneous skills and preferences. Because measuring the output of individual workers is often difficult, it becomes especially important to think about the incentives workers face. Pay for performance may not just induce the higher effort levels, but may also induce workers to select the firm that is the best fit for their skills, effort, and tastes. Personnel economics emphasizes the importance of human resources practices for inducing workers' self-sorting to firms.

Better fit or performance is achieved when complementary people are matched to each other within the firm, or when complementary human resources practices are matched to each other. People are complements when the skills of one enhance those of another within their team. Human resources practices are complements when one practice-such as teamwork-is combined with another practice—such as group-based incentive pay—such that together they raise output more than would either practice independently

Alfred Marshall's ([1890] 1961) famous statement that it is not the economist's business to tell the brewer how to brew beer has not been adhered to when it comes to personnel economics. Personnel economists, at least in their interactions with business students and practitioners, are attempting to use the tools of economics to understand, and even sometimes to guide, practices. 


\section{References}

Akerlof, George, and Kranton, Rachel. 2000. "Economics and Identity.” Quarterly Journal of Economics, 115 (August): 715-53.

Alchian, Armen A., and Demsetz, Harold. 1972. "Production, Information Costs, and Economic Organization.” The American Economic Review, 62(5): 777-95.

Andersson, Fredrik, Matthew Freedman, John Haltiwanger, Julia Lane, and Kathryn Shaw. 2006. "Reaching for the Stars: Who Pays for Talent in Innovative Industries?” National Bureau of Economic Research Working Paper 12435.

Asch, Beth J. 1990. “Do Incentives Matter? The Case of Navy Recruiters.” Industrial and Labor Relations Review, February, 43(special issue): s89-s106.

Autor, David, Lawrence Katz, and Melissa Kearney. 2005. "Rising Wage Inequality: The Role of Composition and Prices.” National Bureau of Economic Research Working Paper 11628.

Autor, David, Lawrence Katz, and Melissa Kearney. 2006. "The Polarization of the U.S. Labor Market.” National Bureau of Economic Research Working Paper 11986.

Autor, David, Lawrence Katz, and Melissa Kearney. Forthcoming. "Trends in U.S. Wage Inequality: Re-Assessing the Revisionists.” Review of Economics and Statistics.

Autor, David H, Frank Levy, and Richard Murnane. 2003. "The Skill Content of Recent Technological Change: An Empirical Exploration”. Quarterly Journal of Economics, 118(4):

1279-1333.

Baily, Martin N. 1977. "On the Theory of Layoffs and Unemployment.” Econometrica 45(5): 1043-63. .

Baron, James, and Michael Hannan. 2002. "Organizational Blueprints for Success in High-Tech Start-Ups: Lessons from the Stanford Project.” California Management Review, Spring, 44(3): 8-36.

Baron, Jim, and David Kreps. 1999. Strategic Human Resources: Frameworks for General Managers. New York: John Wiley.

Bartel, Ann, Casey Ichniowski, and Kathryn Shaw. Forthcoming(November). "How Does Information Technology affect Productivity? Plant-Level Comparisons of Product Innovation, Process Improvement and Worker Skills,”. Quarterly Journal of Economics. Press.

Becker, Gary. 1957. The Economics of Discrimination. Chicago: University of Chicago 
Bloom, Nicholas, and John Van Reenen. 2007. Forthcoming. "Measuring and Explaining Management Practices across Firms and Countries.”Quarterly Journal of Economics, November.

Boning, Brent, Ichniowski, Casey, and Shaw, Kathryn. Forthcoming. "Opportunity Counts: Teams and the Effectiveness of Production Incentives,” Journal of Labor Economics.

Brown, Charles. 1980. “Equalizing Differences in the Labor Market.” Quarterly Journal of Economics, 94(February): 113-34.

Brown, Charles. 1990. "Firms' Choice of Method of Pay." Industrial and Labor Relations Review, February, 43(1): 165S-182S.

Brown, Charles. 1992. "Wage Levels and Methods of Pay." RAND Journal of Economics, 23(Autumn): 366-75.

Chan, William. 1996. "External Recruitment versus Internal Promotion.” Journal of Labor Economics, October, 14(4): 555-70.

Cheung, Steven N. S. 1969. The Theory of Share Tenancy: With Special Application to Asian Agriculture and the First Phase of Taiwan Land Reform. Chicago: University of Chicago Press.

DeVaro, Jed. 2006. “Internal Promotion Competitions in Firms." The Rand Journal of Economics, 37(3), 521-42.

Drago Robert, and Gerald T. Garvey. 1998. "Incentives for Helping on the Job: Theory and Evidence." Journal of Labor Economics, 16(1):1-25.

Drago, R., and Heywood, J. S. 1995. "The Choice of Payment Schemes: Australian Establishment Data.” Industrial Relations, October, 34(4): 507-31.

Dye, Ronald A. 1984.”The Trouble with Tournaments.” Economic Inquiry, 22(1), 14749.

Ehrenberg, Ronald G., and Michael L. Bognanno. 1990. "Do Tournaments Have Incentive Effects?” Journal of Political Economy, 98(6): 1307-24.

Epple, Dennis. 1987. "Hedonic Prices and Implicit Markets: Estimating Demand and Supply Functions for Differentiated Products.” Journal of Political Economy, 95(February): 59_ 80 .

Eriksson, Tor. 1999. "Executive Compensation and Tournament Theory: Empirical Tests on Danish Data.” Journal of Labor Economics, April, 17(2): 262-80. 
Falk, Armin, and Ernst Fehr. 2006. “The Power and Limits of Tournament Incentives the Impact of Sabotage, Social Norms and Loss Aversion.” Unpublished paper.

Fallick, Bruce, Charles A. Fleischmann, and James B. Rebitzer. Forthcoming. “Job Hopping in Silicon Valley: The Microfoundations of a High-Technology Cluster." Review of Economics and Statistics.

Fernie, Sue, and David Metcalf. 1999. "It’s Not What You Pay It's the Way That You Pay It and That's What Gets Results: Jockeys’ Pay and Performance.” Labour: Review of Labour Economics and Industrial Relations, June 13(2): 385-411.

Frank, Robert H. 1984. "Interdependent Preferences and the Competitive Wage Structure.” RAND Journal of Economics, 15(Winter): 510-20.

Frank, Robert H. 1985. Choosing the Right Pond: Human Behavior and the Quest for Status. New York: Oxford University Press.

Frank, Robert H1996. The Winner-Take-All Society. New York: Penguin Books.

Freeman, Richard, and Morris Kleiner. 2005. "The Last American Shoe Manufacturer: Decreasing Productivity and Increasing Profits in the Shift from Piece Rates to Continuous flow production”. Industrial Relations, April, 44(2): 307-30.

General Electric Corporation. 2001. Annual Report.

Gordon, Donald F. 1974. “A Neoclassical Theory of Keynesian Unemployment.” Economic Inquiry, 12(December): 431-59.

Green, Jerry R. and Nancy L. Stokey. 1983. “A Comparison of Tournaments and Contracts.” The Journal of Political Economy, 91(3), 349-64.

Griliches, Zvi. 1977. "Estimating the Returns to Schooling: Some Econometric Problems.” Econometrica, 45(January): 1-22.

Hamilton, Barton, Jack Nickerson, and Hideo Owan. 2003. “Team Incentives and Worker Heterogeneity: An Empirical Analysis of the Impact of Teams on Productivity and Participation.” Journal of Political Economy, June, 111(3): 465-97.

Hausman, Jerry A., and William E. Taylor. 1981. "Panel Data and Unobservable Individual Effects.” Econometrica, 49(November): 1377-98.

Heckman, James. 1979. "Sample Selection Bias as a Specification Error.” Econometrica, 47(January): 153-61. 
Ichniowski, Casey, and Kathryn Shaw. 1995. “Old Dogs and New Tricks: Determinants of the Adoption of Productivity-Enhancing Work Practices.” Brookings Papers on Economic Activity: Microeconomics, 1995, . 1-65.

Ichniowski, Casey, and Kathryn Shaw. 2003. “Connective Capital: Building Problemsolving Networks within Firms.” Unpublished paper.

Ichniowski, Casey, Kathryn Shaw, and Giovanna Prennushi. 1997. "The Effects of Human Resource Management Practices on Productivity: A Study of Steel Finishing Lines.” The American Economic Review, 86(3): 291-313.

Johnson, D. Gale. 1950. "Resource Allocation under Share Contracts.” Journal of Political Economy, 58(2): 111-23.

Kandel, Eugene, and Edward Lazear. "Peer Pressure and Partnerships.” 1992. Journal of Political Economy, 100(August): 801-817.

Knoeber, Charles R., and Walter N. Thurman. 1994. "Testing the Theory of Tournaments: An Empirical Analysis of Broiler Production.” Journal of Labor Economics, April, 12(2): 155-79.

Lawler, Edward E., III, Susan Albers Mohrman, and George Benson. 2001. Organizing for High Performance: Employee Involvement, TQM, Reengineering, and Knowledge Management in the Fortune 1000. San Francisco: Jossey-Bass.

Lawler, Edward E., III, Susan Albers Mohrman, and Gerald E. Ledford Jr. 1995. Creating High Performance Organizations: Practices and Results of Employee Involvement and TQM in Fortune 1000 Companies. San Francisco: Jossey-Bass.

Lazear, Edward P. 1979. “Why Is There Mandatory Retirement?” Journal of Political Economy, 87(6), 1261-84.

Lazear, Edward P. 1986. "Salaries and Piece Rates.” Journal of Business, 59(July): 405-31.

Lazear, Edward P. 1989. "Pay Equality and Industrial Politics.” Journal of Political Economy, 97(June): 561-80.

Lazear, Edward P. 1999a. “Globalization and the Market for Teammates." The Economic Journal, 109(March): C15-C40.

Lazear, Edward P. 1999b. "Personnel Economics: Past Lessons and Future Directions." Presidential Address to the Society of Labor Economists, San Francisco, May 1, 1998. Journal of Labor Economics, April, 17(2): 199-236. 
Lazear, Edward P. 2000. "Performance Pay and Productivity." American Economic Review, December, 90(5): 1346-61.

Lazear, Edward P., and Sherwin Rosen. 1981. "Rank-Order Tournaments as Optimum Labor Contracts.” Journal of Political Economy, October, 89(5): 841-64.

Lazear, Edward, and Kathryn Shaw. Forthcoming. "Wage Structure, Wages, and Mobility." In An International Comparison of the Structure of Wages, ed. Edward Lazear and Kathryn Shaw. University of Chicago.

Lo, Desmond, Mrinal Ghosh, and Francine Lafontaine. 2006. "The Role of Risk, Incentives, and Selection in Salesforce Compensation Contracts.” Unpublished paper, Ross School of Business, University of Michigan, May.

Main, Brian G. M., Charles A. O’Reilly III, and James Wade. 1993. "Top Executive Pay: Tournament or Teamwork?” Journal of Labor Economics, October, 11(4): 606-28.

March, James. 1999. The Pursuit of Organizational Intelligence. Malden, MA: Blackwell Publishers Inc.

Marshall, Alfred P. [1890] 1961. Principles of Economics. New York: Macmillan.

Milgrom, Paul R. 1988. "Employment Contracts, Influence Activities, and Efficient Organization Design." Journal of Political Economy, 96(February): 42-60.

Milgrom, Paul, and John Roberts. 1990. "The Economics of Modern Manufacturing: Technology, Strategy, and Organizations.” American Economic Review, June, 80(3): 511-28.

Nalebuff, Barry J., and Joseph E. Stiglitz. 1983. "Prizes and Incentives: Towards a General Theory of Compensation and Competition.” The Bell Journal of Economics, 14(1), 2143.

O'Reilly III, Charles A. 1995. "Southwest Airlines: Using Human Resources for Competitive Advantage (A)." Stanford Case No. HR-1A. Stanford, CA: Stanford Graduate School of Business.

Oyer, Paul. 1998. "Fiscal Year Ends and Non-Linear Incentive Contracts: The Effect on Business Seasonality.” The Quarterly Journal of Economics, 113(February): 149-85.

Oyer, Paul. Forthcoming. “Salary or Benefits?” Research in Labor Economics.

Parent, Daniel. 1999. "Methods of Pay and Earnings: A Longitudinal Analysis." Industrial and Labor Relations Review, October, 53(1): 71-86. Press.

Pfeffer, Jeffrey. 1994. Competitive Advantage through People. Harvard Business School 
Prendergast, Canice. 1993. "The Role of Promotion in Inducing Specific Human Capital Acquisition.” The Quarterly Journal of Economics, 108(2): 523-534.

Prendergast, Canice, and Robert H. Topel. 1996. "Favoritism in Organizations." Journal of Political Economy, October, 104(5): 958-78.

Roberts, John. 2004. The Modern Firm: Organizational Design for Performance and Growth. Oxford University Press.

Rosen, Sherwin. 1974. "Hedonic Prices and Implicit Markets: Product Differentiation in Pure Competition.” Journal of Political Economy, 82(January/February): 34-55.

Rosen, Sherwin. 1986. "Prizes and Incentives in Elimination Tournaments.” American Economic Review, September, 76(4): 701-715.

Ross, Stephen A. 1973. "The Economic Theory of Agency: The Principal's Problem.” American Economic Review, 63(2): 134-39.

Shearer, Bruce. 2004. "Piece Rates, Fixed Wages and Incentives: Evidence from a Field Experiment.” Review of Economic Studies, 71(April): 513-34.

Stern, Scott. 2004. “Do Scientists Pay to be Scientists?” Management Science, 50(June): 835-53.

Stiglitz, Joseph E. 1975. "Incentives, Risk, and Information: Notes toward a Theory of Hierarchy.” Bell Journal of Economics and Management Science, 6(August): 552-79.

Time. 2000. “GE’s Talent Agency.” December 3.

Thaler, Richard, and Sherwin Rosen. 1976. "The Value of Saving a Life: Evidence from the Labor Market.” In Household Production and Consumption, ed. Nestor E. Terlecky. Studies in Income and Wealth 40. New York: Columbia University Press (for NBER), pp. 41242.

USA Today. 2007. “Home Depot's new CEO is also a GE alum.” January 13. 
Figure 1

Paying for Input versus Paying for Output

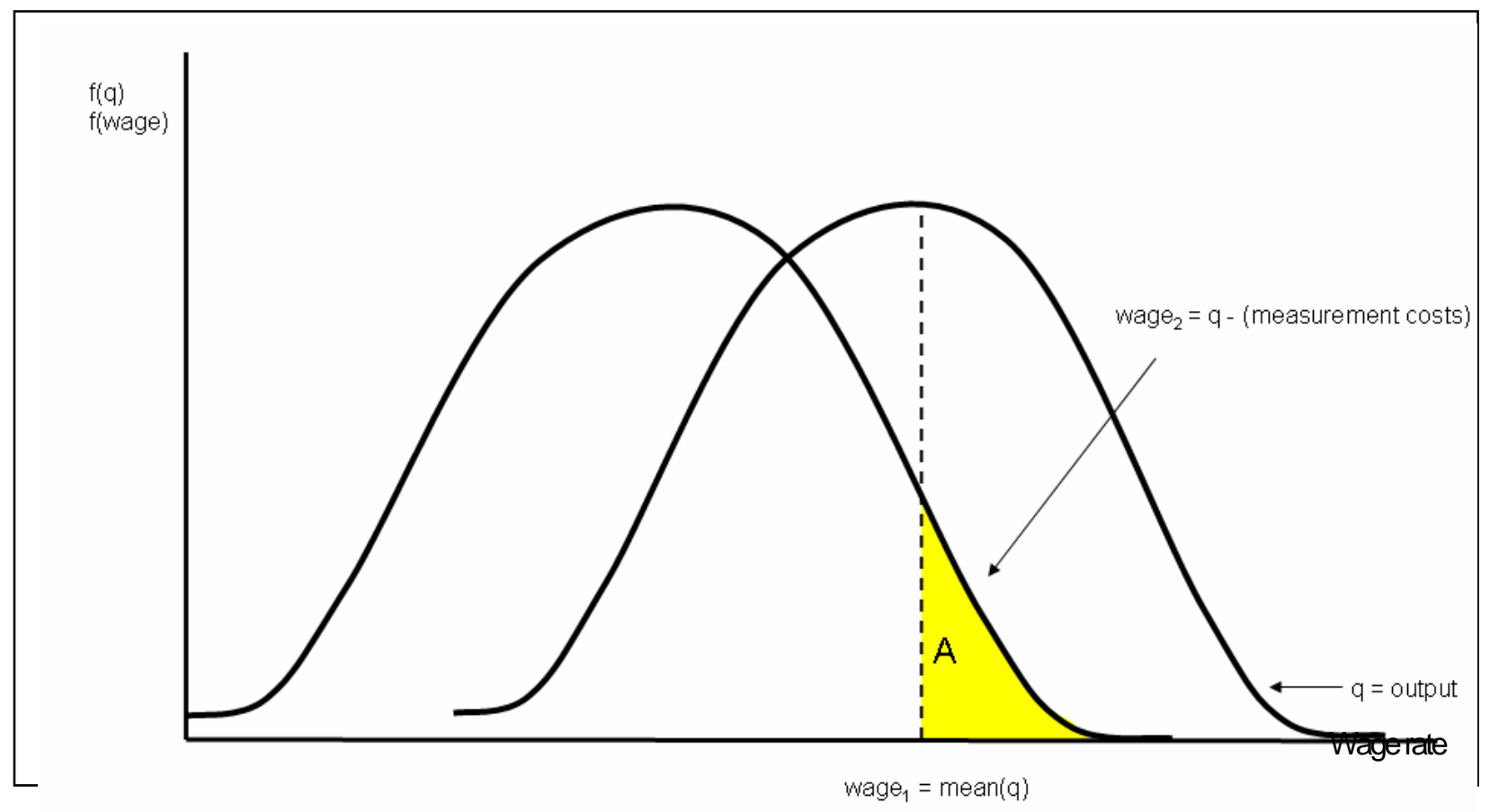

Note: Without measuring individual output (q), the firm pays wage ${ }_{1}$, which is the mean of output across all workers. After incurring fixed measurement costs, the firm pays all individuals the distribution of wages labeled wage ${ }_{2}$. If the firm does not bear these measurement costs, the best workers in area A will leave the firm for other firms that do measure their individual output. 
Figure 2

When to Use Teams

Design D

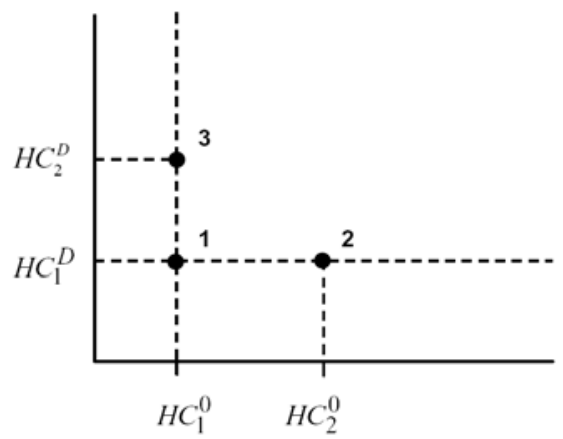

A: Team of Experts
Design D

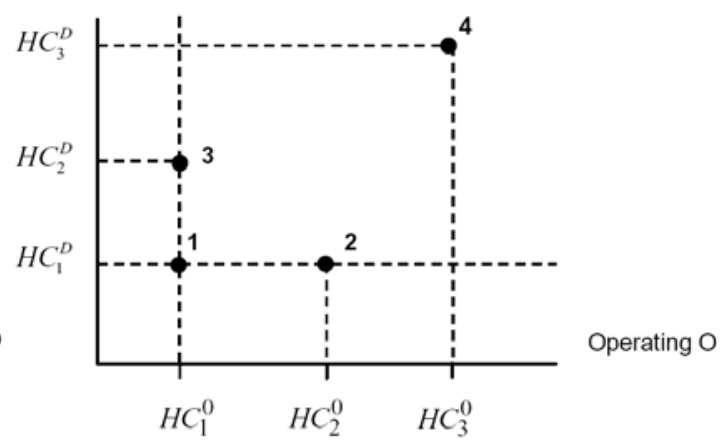

B: Hierarchy of Generalists 
Table 1

\section{Human Resource Management Practices in Large Firms}

\begin{tabular}{|c|c|c|c|c|c|c|}
\hline \multicolumn{7}{|c|}{$\%$ of firms with ... } \\
\hline & $\begin{array}{l}\text { individual } \\
\text { incentives, } \\
\text { like } \\
\text { performance } \\
\text { bonuses }\end{array}$ & $\begin{array}{l}\text { more than } \\
20 \% \text { of } \\
\text { employees } \\
\text { having } \\
\text { individual } \\
\text { incentives }\end{array}$ & gainsharing & $\begin{array}{l}\text { more than } \\
20 \% \text { of } \\
\text { employees } \\
\text { having } \\
\text { gainsharing }\end{array}$ & $\begin{array}{l}\text { skill-based } \\
\text { pay }\end{array}$ & $\begin{array}{l}\text { more than } \\
20 \% \text { of } \\
\text { employees } \\
\text { having skill- } \\
\text { based pay }\end{array}$ \\
\hline 1987 & 83 & 38 & 26 & 7 & 40 & 15 \\
\hline 1990 & 90 & 45 & 39 & 11 & 51 & 17 \\
\hline 1993 & 90 & 50 & 42 & 16 & 60 & 23 \\
\hline 1996 & 91 & 57 & 45 & 19 & 72 & 22 \\
\hline 1999 & 93 & 67 & 53 & 24 & 72 & 26 \\
\hline
\end{tabular}

\begin{tabular}{|l|l|l|l|l|l|}
\hline \multicolumn{7}{|l|}{ B: Teamwork } \\
& & $\begin{array}{l}\text { 20\% or more } \\
\text { employees in } \\
\text { teams }\end{array}$ & $\begin{array}{l}\text { \% of firms with . . } \\
\text { self-managed } \\
\text { teams }\end{array}$ & $\begin{array}{l}\text { 20\% or more } \\
\text { in self- } \\
\text { managed teams }\end{array}$ & $\begin{array}{l}\text { more than 20\% } \\
\text { given team- } \\
\text { building skills }\end{array}$ \\
\hline 1987 & 70 & 37 & 27 & 7 & 54 \\
\hline 1990 & 86 & 51 & 47 & 10 & 55 \\
\hline 1993 & 91 & 65 & 62 & 20 & 75 \\
\hline 1996 & 94 & 66 & 78 & 32 & 78 \\
\hline 1999 & 84 & 61 & 72 & 28 & 76 \\
\hline
\end{tabular}

Source: Lawler, Mohrman, and Benson, (2001), Lawler, Mohrman, and Ledford (1995). 
Table 2

Percentage of Individuals Covered by Employment-Based Health Insurance

(by family income)

$\begin{array}{lrcl}\text { Family Income } & \text { Total } & \begin{array}{l}\text { Covered by } \\ \text { employment-based } \\ \text { health care }\end{array} & \begin{array}{l}\text { As a } \\ \text { percent of } \\ \text { total }\end{array} \\ \text { Whites } & 240,909 & 147,367 & \\ \quad \text { All Whites } & 52,424 & 11,996 & 0.61 \\ <\$ 25,000 & 59,753 & 32,561 & 0.23 \\ \text { \$25,000-\$49,000 } & 46,360 & 34,111 & 0.54 \\ \text { \$50,000-\$74,999 } & 82,372 & 68,699 & 0.74 \\ \text { \$75,000 or more } & & & 0.83 \\ & & & \\ \text { Blacks } & 36,965 & 18,003 & 0.49 \\ \text { All Blacks } & 14,578 & 3,156 & 0.22 \\ <\$ 25,000 & 9,944 & 5,483 & 0.55 \\ \text { \$25,000-\$49,000 } & 5,844 & 4,042 & 0.69 \\ \text { \$50,000-\$74,999 } & 6,599 & 5,322 & 0.81 \\ \$ 75,000 \text { or more } & & & \end{array}$

Source: U.S. Census Bureau, Current Population Survey, 2006, Annual Social and Economic Supplement. 